\title{
Hepatocellular and Cholangiolar Carcinoma-Derived Cell Lines Reveal Distinct Sets of Chromosomal Imbalances
}

\author{
Ludwig Wilkens ${ }^{\mathrm{a}, \mathrm{b}} \quad$ Caroline Hammer $^{\mathrm{a}}$ Sabine Glombitza ${ }^{\mathrm{b}}$ \\ Dominique-Elisabeth Müller ${ }^{\mathrm{a}}$ \\ ${ }^{\mathrm{a}}$ Institute of Pathology, University of Bern, Bern, Switzerland; ${ }^{\mathrm{b}}$ Klinikum Region Hannover, Hannover, Germany
}

\section{Key Words}

Hepatocellular carcinoma - Cholangiocellular carcinoma . Cytogenetics · Chromosomal aberrations · Array CGH · Cell lines

\begin{abstract}
Objectives: Hepatocellular carcinoma (HCC) and cholangiolar carcinoma (CC) cell lines are used to analyze the basic mechanisms of carcinogenesis and target therapies. However, it is not yet clear which chromosomal aberrations are to be typically expected in such cell lines. It is also not clear whether there are prerequisites for in vitro growth on the genomic and/or expression level. We therefore analyzed HCC and CC cell lines for typical genetic settings. Methods: The HCC cell lines HLE, HLF, Huh7, HepG2 and Hep3b and the CC cell lines EGI1, MzCha1 and TFK-1 were analyzed using high-density arrays for comparative genomic hybridization (aCGH; 244,000 oligonucleotides). Additional fluorescence in situ hybridization analyses were done to confirm the aCGH results and to add information regarding the aneuploidy of cell lines. Results: The gain of 1q, in particular q21-22, was detected in all HCC cell lines also as a partial loss of 13q. In
\end{abstract}

contrast, a loss of $8 p$ in combination with a relative gain of $8 \mathrm{q}$ was seen in all CC but no HCC cell lines. Interestingly, a gain of $17 q$ was seen in all cell lines. These aberrations are also well documented for surgical tumor specimens. Besides these imbalances, the cell lines revealed imbalances for $11 p$, $12 p, 14 q, 16 p, 16 q, 21 q$ and $22 q$, respectively, only rarely seen in surgical tumor specimens. These aberrations could be of importance for the in vitro cultivation of tumor cells. Structural aberrations were accompanied by aneuploidy in 3 of 5 $\mathrm{HCC}$ cell lines and 2 of $3 \mathrm{CC}$ cell lines. Ploidy status was not correlated to any of the imbalances mentioned above. Conclusions: HCC and CC cell lines revealed characteristic chromosomal imbalances similar to those seen in surgical tumor specimens including chromosomes 1, 8, 13 and 17, respectively. These aberrations are characteristic of the histogenetic origin of the tumor cells. However, the chromosomal imbalances that occurred probably led to the ability of tumor cells to grow in vitro.

Copyright $\odot 2012$ S. Karger AG, Basel

\section{KARGER}

Fax +4161306 1234 E-Mail karger@karger.ch www.karger.com
(C) 2012 S. Karger AG, Basel

$1015-2008 / 12 / 0793-0115 \$ 38.00 / 0$

Accessible online at:

www.karger.com/pat
Ludwig Wilkens, MD

Institute of Pathology, University of Bern

Murtenstrasse 31

$\mathrm{CH}-3010$ Bern (Switzerland)

Tel. +41 31632 3276, E-Mail ludwig.wilkens@ @athology.unibe.ch 


\section{Introduction}

Hepatocellular carcinoma (HCC) is the fourth most common malignant cancer, with more than one million patients affected worldwide per year $[1,2]$. Large-scale gene expression profiling has provided important insights into the biology of HCC with regard to classification, etiology, survival prediction and identification of signaling pathways that may possibly serve as therapeutic targets [3-7]. Cholangiolar carcinoma (CC) represents about $10-20 \%$ of all hepatobiliary tumors [8] with strong geographic variations [9]. Clinical outcome is still poor despite new therapeutic approaches similar to HCC [10].

Cell lines derived from HCC and CC surgical specimens serve as in vitro systems to identify candidate genes of carcinogenesis and the effect of drugs and toxins on liver-derived cells. These tumor cells serve also as dynamic systems which can be altered, e.g. by gene silencing. Moreover, fixation artifacts, which are a major problem in formalin-fixed and paraffin-embedded specimens for genetic analyses, are not an issue in cell lines. This can also be said for the admixture of nonneoplastic cells typically seen in surgical tumor specimens.

Despite their frequent use for research purposes, it is not clear whether these cell lines are representative and mirror the mechanisms responsible for malignancy in vivo. Indeed, to the best of our knowledge, no systematic molecular cytogenetic analysis has yet been performed for hepatocytic and cholangiolar tumor cell lines in regard to this problem; it is therefore not clear whether or not cell lines in their cy togenetic findings are comparable to surgical tumor specimens grown in vivo. It is also not clear if there are mandatory chromosomal imbalances for maintaining tumor cells.

To answer these questions we focused on the detection of chromosomal aberrations in HCC- and CC-derived cell lines using an array-based high density comparative genomic hybridization (aCGH) system. The results were compared with regard to the hepatocellular and cholangiocellular origin of tumor cells analyzed, as well as to the findings reported in the literature for surgical tumor specimens.

\section{Material and Methods}

\section{Cell Lines}

HCC cell lines Hep3b and HepG2 were supplied by DSMZ (Braunschweig, Germany). Carcinoma cell lines of cholangiolar differentiation EGI-1 and TFK-1 were also supplied by DSMZ, whereas Mz-Cha-1 came from ATCC (Manassas, Va., USA). Two of these cell lines (MzChA-1 and TFK-1) were available also as tumor specimens grown in a mouse model (nude mice; NMRI nu/ nu). Cell lines HLF, HLE and Huh7 were kindly provided by Prof. Huh (Dept. of Cell Biology, Okayama University).

\section{Cell Cultures}

Tumor cell lines were incubated in DMEM with $10 \%$ fetal calf serum supplemented with glutamine and penicillin/streptomycin at $37^{\circ} \mathrm{C}$ in a $5 \% \mathrm{CO}_{2}$ atmosphere in $25-\mathrm{cm}^{2}$ tissue flasks (Oxoid TPP 90025, Oxoid, Pratteln, Switzerland).

Arrays for Comparative Genomic Hybridization

aCGH was performed using a high-density array system with 244,000 oligonucleotides on a chip (Cat. No. G4411B, Agilent, Waldbronn, Germany), covering the complete genome in an average of approximately 5-13 kB. DNA was isolated using the QIAamp DNA Mini kit, (Qiagen Cat. No. 51304), following the supplier's instructions for cultured cells.

Labeling and hybridization were also done as described by the supplier. As a reference, DNA of a female donor was taken (Cat. No. G1521, Promega, Mannheim, Germany). Hybridization was performed for $40 \mathrm{~h}$ at $65^{\circ} \mathrm{C}$ in a hybridization oven (Agilent G2545A).

Validation of aCGH Results by Fluorescence in situ

Hybridization

Fluorescence in situ hybridization (FISH) was performed as described earlier in detail [11]. For all cell lines, 5 centromere- and 10 locus-specific probes were applied (all were supplied by Abbott/Vysis, Baar, Switzerland; see table 2). Locus-specific probes were used to directly confirm the aCGH results. Centromere-specific probes were used to determine the polyploidy of tumor cells as this cannot be done by aCGH, due to technical reasons.

\section{Data Analysis}

Array images were acquired using a laser scanner (Agilent Scanner System 2605, Agilent). Hybridization spots on a slide were normalized with feature extraction software (version 9.5.3.1.) and processed as described below.

Data were imported to the Genomic Workbench software program version 5.0.14 (Agilent). The search for common aberrations was performed using the ADM1 algorithm based on a t test. The other parameters were set as follows: threshold 6 (the number of spots necessary to indicate an aberration), applied genome hg18 (data set of annotations available at the time of analyses), $\mathrm{p}$-value threshold of 0.05 , overlap 0.9 (indicates covering of the complete genome; more information provided on the supplier's website). Aberrations were searched with a resolution of up to $10 \mathrm{kB}$; those found for less than 3 probes only were not regarded for further analysis.

\section{Results}

\section{Overall Findings in HCC Cell Lines}

Concordant gains were detected by aCGH in all 5 cell lines for the regions of chromosomes 1, 2, 4, 5, 6, 7, 11, 12, $14,16,17,19,20,21$ and 22, respectively. Detailed annotations of these aberrations are given in table 1 , with ex- 
Table 1. Gains and losses occurring in either all HCC cell lines and/or all CC cell lines

\begin{tabular}{|c|c|c|c|c|c|c|c|c|c|c|c|}
\hline \multirow{2}{*}{$\begin{array}{l}\text { Chro- } \\
\text { mo- } \\
\text { some }\end{array}$} & \multirow{2}{*}{$\begin{array}{l}\text { Chromo- } \\
\text { some } \\
\text { band }\end{array}$} & \multicolumn{4}{|c|}{ Gained region } & \multirow{2}{*}{$\begin{array}{l}\text { Chro- } \\
\text { mo- } \\
\text { some }\end{array}$} & \multirow{2}{*}{$\begin{array}{l}\text { Chromo- } \\
\text { some } \\
\text { band }\end{array}$} & \multicolumn{4}{|c|}{ Gained region } \\
\hline & & start & stop & size & $\begin{array}{l}\text { probes } \\
\mathrm{n}\end{array}$ & & & start & stop & size & $\begin{array}{l}\text { probes } \\
\mathrm{n}\end{array}$ \\
\hline \multirow{2}{*}{\multicolumn{6}{|c|}{$\begin{array}{l}\text { Gains } \\
1\end{array}$}} & & $\mathrm{q} 12.3$ & $61,135,690$ & $65,530,381$ & $4,394,692$ & 622 \\
\hline & & & & & & & & & & & \\
\hline \multirow[t]{8}{*}{$\mathrm{HCC}$} & p36.33 & 836,343 & $3,070,895$ & $2,234,553$ & 300 & & & & & & \\
\hline & $\mathrm{q} 21.2$ & $144,112,595$ & $150,290,477$ & $6,177,883$ & 488 & & $\mathrm{q} 12.3$ & $65,558,691$ & $65,591,699$ & 33,009 & 8 \\
\hline & $\mathrm{q} 22$ & $151,689,698$ & $155,102,486$ & $3,412,789$ & 486 & & $\mathrm{q} 12.3$ & $65,607,044$ & $69,994,848$ & $4,387,805$ & 487 \\
\hline & q23.2-24.1 & $159,307,849$ & $159,758,930$ & 451,082 & 77 & \multirow{9}{*}{$\begin{array}{l}12 \\
H C C\end{array}$} & & & & & \\
\hline & $\mathrm{q} 32.2$ & $198,544,050$ & $204,835,991$ & $6,291,942$ & 680 & & & & & & \\
\hline & $\mathrm{q} 32.2$ & $209,723,576$ & $211,369,675$ & $1,646,100$ & 167 & & p13.33 & 192,203 & $3,443,729$ & $3,251,527$ & 361 \\
\hline & $\mathrm{q} 42.12$ & $221,318,190$ & $229,887,283$ & $8,569,094$ & 777 & & p13.33 & $6,227,581$ & $7,249,423$ & $1,021,843$ & 158 \\
\hline & $\mathrm{q} 42.2$ & $232,809,040$ & $234,814,928$ & $2,005,889$ & 175 & & p13.1 & $31,375,253$ & $32,716,802$ & $1,341,550$ & 125 \\
\hline$C C$ & $\mathrm{q} 42.3$ & $246,794,322$ & $246,875,192$ & 80,871 & 12 & & p12.1 & $47,265,452$ & $56,560,248$ & $9,294,797$ & 1,319 \\
\hline & & & & & & & q13.13 & $107,420,123$ & $112,882,430$ & $5,462,308$ & 579 \\
\hline 2 & & & & & & & q13.2 & $119,012,615$ & $124,383,410$ & $5,370,796$ & 605 \\
\hline \multirow[t]{13}{*}{ HCC } & $\begin{array}{l}\mathrm{p} 22.1 \\
\mathrm{p} 16.3\end{array}$ & $42,844,630$ & $47,734,656$ & $4,890,027$ & 468 & & $\mathrm{q} 14.1$ & $130,868,078$ & $131,928,007$ & $1,059,930$ & 127 \\
\hline & p16.3 & $53,563,088$ & $55,893,540$ & $2,330,453$ & 216 & \multirow{3}{*}{$\begin{array}{l}\mathbf{1 4} \\
H C C \\
\end{array}$} & \multirow{3}{*}{ q31.1 } & \multirow{3}{*}{$21,719,393$} & \multirow{3}{*}{$24,042,410$} & \multirow{3}{*}{$2,323,018$} & \multirow{3}{*}{337} \\
\hline & p 16.1 & $60,584,878$ & $62,292,786$ & $1,707,909$ & 170 & & & & & & \\
\hline & p14 & $64,651,967$ & $65,783,515$ & $1,131,549$ & 105 & & & & & & \\
\hline & p14 & $69,218,676$ & $74,795,481$ & $5,576,806$ & 609 & \multirow{3}{*}{$\begin{array}{l}\mathbf{1 6} \\
H C C\end{array}$} & & & & & \\
\hline & p11 & $84,919,087$ & $86,135,288$ & $1,216,202$ & 148 & & p13.12 & $15,022,821$ & $22,666,085$ & $7,643,265$ & 579 \\
\hline & \multirow{2}{*}{$\begin{array}{l}\text { q36.3 } \\
\text { q36.3 }\end{array}$} & $216,601,776$ & $217,266,211$ & 664,436 & 84 & & p11.2 & $28,144,761$ & $31,458,436$ & $3,313,676$ & 388 \\
\hline & & $218,397,811$ & $220,461,168$ & $2,063,358$ & 299 & & & & & & \\
\hline & $\mathrm{q} 37.1$ & $231,685,211$ & $233,431,082$ & $1,745,872$ & 209 & 17 & & & & & \\
\hline & $\mathrm{q} 37.1$ & $233,437,021$ & $234,508,466$ & $1,071,446$ & 119 & & p13.3 & 585,856 & $8,318,441$ & $\begin{array}{l}7,732,586 \\
3,025760\end{array}$ & $\begin{array}{r}983 \\
278\end{array}$ \\
\hline & $\mathrm{q} 37.3$ & $238,402,477$ & $239,146,299$ & 743,823 & 84 & & p11.2 & $16,204,925$ & $19,230,693$ & $3,025,769$ & 278 \\
\hline & $\mathrm{q} 37.3$ & $241,000,846$ & $242,366,051$ & $1,365,206$ & 151 & & p11.2 & $22,978,686$ & $28,360,521$ & $5,381,836$ & 618 \\
\hline & & & & & & & & $31,102,705$ & $33,210,431$ & $2,107,727$ & 193 \\
\hline 4 & & & & & & & q11.2-qter & $33,241,958$ & $78,154,619$ & $44,912,662$ & 4,380 \\
\hline HCC & p16.3 & 418,532 & $4,281,963$ & $3,863,432$ & 399 & CC & $\mathrm{q} 21.2$ & $40,812,631$ & $40,926,354$ & 113,724 & 13 \\
\hline & p16.1 & $6,276,325$ & $9,681,373$ & $3,405,049$ & 330 & & q21.32-qter & $47,566,333$ & $78,638,667$ & $31,072,335$ & 2,796 \\
\hline & p14 & $38,984,514$ & $39,644,620$ & 660,107 & 82 & & & & & & \\
\hline 5 & & & & & & HCC & p13.3 & 601,828 & 623,033 & 21,206 & 5 \\
\hline HCC & p15.33 & 580,352 & $1,274,466$ & 694,115 & 77 & & p13.3 & $1,977,231$ & $2,074,547$ & 97,317 & 15 \\
\hline$C C$ & q13.1 & $65,471,109$ & $65,481,190$ & 10,082 & 2 & & q13.12- & & & & \\
\hline & $\mathrm{q} 23.1$ & $115,248,273$ & $115,461,904$ & 213,632 & 21 & & 13.32 & $38,068,451$ & $46,538,616$ & $8,470,166$ & 937 \\
\hline $\begin{array}{l}6 \\
H C C\end{array}$ & & & & & 190 & & $\begin{array}{l}\text { q13.32- } \\
\text { q13.43 }\end{array}$ & $46,547,693$ & $63,017,721$ & $16,470,029$ & 2,028 \\
\hline & p21.1 & $44,309,561$ & $44,391,933$ & 82,373 & 18 & 20 & & & & & \\
\hline 7 & & & & & & HCC & p13 & 44,096 & 132,255 & 88,160 & 17 \\
\hline HCC & p22.3 & 314,709 & $2,985,284$ & $2,670,576$ & 286 & & p13 & 137,865 & $25,821,265$ & $25,683,401$ & 2,218 \\
\hline & $\mathrm{p} 22.2$ & $4,527,086$ & $6,743,967$ & $2,216,882$ & 258 & & p11.1 & $26,023,584$ & $26,097,070$ & 73,487 & 3 \\
\hline & p13 & $43,614,252$ & $45,151,855$ & $1,537,604$ & 204 & & q11.1-13.31 & $29,297,070$ & $55,179,441$ & $25,882,372$ & 2,357 \\
\hline & & & & & & & q13.33 & $60,039,625$ & $62,184,038$ & $2,144,414$ & 304 \\
\hline CC & q13.2-qter & $67,548,433$ & $146,265,046$ & $78,716,614$ & 6,078 & 21 & & & & & \\
\hline 11 & & & & & & & $\begin{array}{l}\mathrm{q} 22.3 \\
\mathrm{q} 22.3\end{array}$ & $\begin{array}{l}43,069,742 \\
43,979,106\end{array}$ & $\begin{array}{l}43,773,885 \\
45,896,575\end{array}$ & $\begin{array}{l}704,144 \\
1,917,470\end{array}$ & $\begin{array}{l}100 \\
309\end{array}$ \\
\hline HCC & p15.5 & 310,683 & $3,905,365$ & $3,594,683$ & 418 & & & & & & \\
\hline & p15.4 & $8,663,051$ & $9,824,020$ & $1,160,970$ & 140 & 22 & & & & & \\
\hline & p15.2 & $16,732,726$ & $18,688,187$ & $1,955,462$ & 225 & & q11.1-13.1 & $16,614,966$ & $37,683,716$ & 21,068,751 & 2,513 \\
\hline & p11.12 & $46,099,012$ & $48,001,739$ & $1,902,728$ & 220 & & & $37,718,469$ & $39,344,767$ & $1,626,299$ & 220 \\
\hline
\end{tabular}


Table 1 (continued)

\begin{tabular}{|c|c|c|c|c|c|}
\hline \multirow{2}{*}{$\begin{array}{l}\text { Chro- } \\
\text { mo- } \\
\text { some }\end{array}$} & \multirow{2}{*}{$\begin{array}{l}\text { Chromo- } \\
\text { some } \\
\text { band }\end{array}$} & \multicolumn{4}{|c|}{ Gained region } \\
\hline & & start & stop & size & $\begin{array}{l}\text { probes } \\
\mathrm{n}\end{array}$ \\
\hline \multicolumn{6}{|l|}{ Losses } \\
\hline \multirow[t]{2}{*}{$C C$} & $\mathrm{p} 21.1$ & $60,357,546$ & $60,420,986$ & 63,441 & 9 \\
\hline & p21.1 & $60,437,660$ & $60,595,171$ & 157,512 & 18 \\
\hline \multicolumn{6}{|l|}{4} \\
\hline HCC & $\mathrm{q} 22.1-28.3$ & $90,267,740$ & $133,126,058$ & $42,858,319$ & 2,990 \\
\hline \multicolumn{6}{|l|}{6} \\
\hline \multirow{2}{*}{ CC } & q25.3 & $158,997,666$ & $159,011,514$ & 13,849 & 3 \\
\hline & $\mathrm{q} 25.3$ & $162,263,463$ & $162,627,793$ & 364,331 & 39 \\
\hline \multicolumn{6}{|l|}{8} \\
\hline CC & $\mathrm{p} 23.1$ & $12,275,978$ & $12,285,664$ & 9,687 & 2 \\
\hline \multicolumn{6}{|l|}{9} \\
\hline \multirow[t]{5}{*}{$\mathrm{HCC}$} & $\mathrm{p} 24.3$ & $1,146,909$ & $1,898,135$ & 751,227 & 56 \\
\hline & p23 & $9,067,723$ & $12,203,822$ & $3,136,100$ & 171 \\
\hline & $\mathrm{p} 21.3$ & $22,271,486$ & $25,899,546$ & $3,628,061$ & 160 \\
\hline & p21.1 & $28,607,433$ & $28,735,187$ & 127,755 & 16 \\
\hline & p13.3 & $30,347,026$ & $30,425,535$ & 78,510 & 5 \\
\hline \multicolumn{6}{|l|}{13} \\
\hline \multirow[t]{4}{*}{ HCC } & $\mathrm{q} 14.12$ & $52,551,793$ & $53,879,567$ & $1,327,775$ & 50 \\
\hline & $\mathrm{q} 21.1-21.3$ & $55,111,599$ & $62,308,736$ & $7,197,138$ & 358 \\
\hline & $\mathrm{q} 21.3-22.2$ & $62,338,814$ & $75,553,983$ & $13,215,170$ & 829 \\
\hline & $\mathrm{q} 22.2-31.3$ & $75,612,338$ & $90,614,492$ & $15,002,155$ & 772 \\
\hline \multicolumn{6}{|l|}{14} \\
\hline HCC & $\mathrm{q} 11.1$ & $82,884,987$ & $87,124,061$ & $4,239,075$ & 165 \\
\hline \multicolumn{6}{|l|}{18} \\
\hline \multirow[t]{3}{*}{$\mathrm{HCC}$} & $\mathrm{q} 12.1$ & $35,382,981$ & $39,656,201$ & $4,273,221$ & 234 \\
\hline & $\mathrm{q} 21.1$ & $47,077,902$ & $49,595,012$ & $2,517,111$ & 186 \\
\hline & $\mathrm{q} 21.32$ & $59,793,733$ & $63,780,372$ & $3,986,640$ & 196 \\
\hline
\end{tabular}

amples in figures 1-4. Losses were seen for the regions of chromosomes 4, 9, 13, 14 and 18 . Aberrations spanned a length of from 21 up to $44,913 \mathrm{kB}$ (from 5 up to 4,380 spots on the array).

FISH analysis was done to confirm the aCGH results. Overall, there was a close correlation of FISH and aCGH results; findings were in concord in 48 of 50 analyses performed with locus-specific probes (table 2). By applying centromere-specific probes we found a polyploidy, indicated by a mean of $>2.50$ signals/nucleus, in 3 of $5 \mathrm{HCC}$ cell lines, i.e. HLE, Huh7 and Hep3b.

We compared these aberrations found by aCGH with those obtained in surgical specimens and reported by Moinzadeh et al. [12]. Overall, there was a clear agree- ment between imbalances seen in these specimens and in the cell lines of our study; however, the percentage of cases of specific aberration differed. Whereas in the surgical specimens the number of affected cases was maximally about $55 \%$, aberrations were seen in part in all our samples (table 3).

\section{Overall Findings in CC Cell Lines}

Gains were detectable in all 3 cell lines for chromosomes 1, 5, 8 and 17, respectively. Losses in all 3 cell lines were seen for parts of chromosomes 3, 6 and 8 , respectively. The shortest aberration spanned $10 \mathrm{kB}$ (2 spots) and the longest covered $78,716,614 \mathrm{kB}(6,078$ spots $)$ as listed in table 1 .

These results were confirmed by FISH, using the locus-specific probes in 28 of 30 analyses. Polyploidy was seen in 2 of 3 cell lines (EGI1 and MzCha-1).

Our data were compared to those given for surgical tumor specimens in the progenetix database analyzed by conventional and/or aCGH. In this database, the most frequent aberrations occurring in at least $30 \%$ of cases were losses for $1 \mathrm{p}$ and $6 \mathrm{q}$, and gains for $8 \mathrm{q}, 17 \mathrm{q}$ and $20 \mathrm{q}$, respectively. In our CC cell lines we were able to confirm gains for chromosomes $8 \mathrm{q}$ and $17 \mathrm{q}$, and a loss of $6 \mathrm{q}$, respectively (table 3 ).

Based on the two main tasks of our study, we separated these findings into 2 main groups.

(1) Aberrations of hepatocellular or cholangiocellular origin:

(a) detectable in all HCC cell lines but in none of the CC cell lines

(b) detectable in all CC cell lines but in none of the HCC cell lines

(c) occurring in all HCC and CC cell lines

(2) Aberrations occurring in all HCC or CC cell lines but rarely reported in surgical tumor specimens $(<5 \%)$.

Within these groups we found chromosomal imbalances as follows:

\section{Group 1a}

In all HCC cell lines, gains of chromosomal material were seen for the long arm of chromosome 1 including bands q21, q22, q23.2-24.1, q32.2, q42.12 and q42.2, respectively (fig. 1). In addition, $1 \mathrm{p}$ demonstrated a gain for the region $\mathrm{p} 36.33$.

In 13q, we found chromosome bands q14.11-q31.3 to be a commonly lost region in all HCC cell lines (fig. 3). Surprisingly, none of the CC cell lines demonstrated this aberration. As a loss of $13 \mathrm{q}$ is reported to be correlated to a low differentiation of carcinoma cells, we looked for the 
Table 2. FISH analysis was done for locus-specific probes to confirm the results of aCGH

\begin{tabular}{|c|c|c|c|c|c|c|c|c|c|c|}
\hline & $\begin{array}{l}\text { 1p36/ } \\
\text { TP73 }\end{array}$ & $\begin{array}{l}\text { 1q25/ } \\
\text { ABL2 }\end{array}$ & $\begin{array}{l}6 \mathrm{q} 23 \\
\text { MYB }\end{array}$ & $\begin{array}{l}\text { 8q24/ } \\
\text { CMYC }\end{array}$ & $\begin{array}{l}\text { 13q14/ } \\
\mathrm{Rb} 1\end{array}$ & $\begin{array}{l}17 q 11.2 / \\
\text { Her2 }\end{array}$ & $\begin{array}{l}\text { 19p13 } \\
\text { MAN2B1 }\end{array}$ & $\begin{array}{l}19 \mathrm{q} 13 \\
\text { CRX }\end{array}$ & $\begin{array}{l}20 \mathrm{q} 12 \\
\mathrm{D} 20 \mathrm{~S} 108\end{array}$ & $20 q 13.2$ \\
\hline HLE & yes! & yes & yes & yes & yes & yes & yes & yes & yes & yes \\
\hline Huh7 & yes & yes & yes & no! & yes & yes & yes & yes & yes & yes \\
\hline HLF & yes & yes & yes & yes & yes & yes & yes & yes & yes & yes \\
\hline HepG2 & yes & yes & yes & yes & yes & yes & yes & yes & yes & yes \\
\hline Hep3b & yes & yes & no & yes & yes & yes & yes & yes & yes & yes \\
\hline EGI-1 & yes & yes & yes & yes & yes & yes & yes & yes & yes & yes \\
\hline MzCha-1 & yes & yes & yes & yes & yes & yes & yes & no & yes & yes \\
\hline \multirow[t]{2}{*}{ TFK-1 } & yes & yes & yes & yes & yes & yes & yes & yes & yes & no \\
\hline & CEP1 & CEP3 & CEP7 & CEP8 & CEP17 & $\begin{array}{l}\text { Mean } \\
\text { number } \\
\text { of signals }\end{array}$ & \multicolumn{4}{|l|}{ Poliploidy } \\
\hline HLE & 1.10 & 3.58 & 2.34 & 3.35 & 4.07 & 2.89 & yes & & & \\
\hline Huh7 & 2.00 & 2.61 & 2.78 & * & 2.98 & 2.59 & yes & & & \\
\hline HLF & 1.05 & 2.09 & * & 2.00 & 3.97 & 2.28 & no & & & \\
\hline HepG2 & 2.03 & 2.14 & 2.95 & 1.96 & 2.32 & 2.28 & no & & & \\
\hline Hep3b & 3.64 & 3.21 & 3.08 & 3.19 & 3.07 & 3.24 & yes & & & \\
\hline EGI-1 & 2.84 & 3.20 & 2.15 & 3.98 & 3.80 & 3.19 & yes & & & \\
\hline MzCha-1 & 2.83 & * & 3.69 & 2.80 & 3.62 & 3.23 & yes & & & \\
\hline TFK-1 & 1.96 & 2.08 & 1.97 & 2.01 & 1.98 & 2.00 & no & & & \\
\hline
\end{tabular}

Concordant results were seen in 48 of 50 analyses done in HCC cell lines and in 28 of 30 hybridizations in CC cell lines. In addition, centromeric probes were used to define ploidy status. A clearly increased number of chromosomes with more than 2.5 signals/ nucleus was revealed in 3 of 5 HCC cell lines and in 2 of 3 CC cell lines.

$!=\mathrm{aCGH}$ result confirmed/not confirmed by FISH. * no data obtained for this experiment.

Table 3. The most frequently occurring chromosomal imbalances in surgical specimens of HCC and CC occurring in at least $20 \%$ of tumor samples

\begin{tabular}{|c|c|c|c|c|}
\hline \multirow{2}{*}{$\begin{array}{l}\text { Chromosomal } \\
\text { region }\end{array}$} & \multicolumn{2}{|c|}{ Surgical specimens } & \multicolumn{2}{|l|}{ HCC cell lines } \\
\hline & gain/loss & $\begin{array}{l}\% \text { of cases } \\
\text { with aberration }\end{array}$ & $\begin{array}{l}\text { corresponding } \\
\text { results }\end{array}$ & $\begin{array}{l}\text { number of cell lines } \\
\text { with aberration }\end{array}$ \\
\hline $1 \mathrm{q} 21.1-\mathrm{q} 44$ & gain & $>55$ & yes & $5(100 \%)$ \\
\hline $4 \mathrm{q} 21.1-\mathrm{q} 35$ & loss & $>30$ & yes & $5(100 \%)$ \\
\hline 8p21.1-p22 & loss & $>35$ & yes & $4(80 \%)$ \\
\hline \multirow[t]{2}{*}{$8 \mathrm{q} 22.1-\mathrm{q} 24.3$} & gain & $>45$ & yes & $4(80 \%)$ \\
\hline & & & \multicolumn{2}{|l|}{ CC cell lines } \\
\hline 1p36-pter & loss & $>30$ & no & $1(20 \%)$ \\
\hline 6qcen-qter & loss & $>35$ & yes & $3(100 \%)$ \\
\hline 8q11.2-qter & gain & $>30$ & yes & $3(100 \%)$ \\
\hline $17 \mathrm{p} 13$ & loss & & yes & $3(100 \%)$ \\
\hline 17qcen-qter & gain & $>30$ & yes & $3(100 \%)$ \\
\hline 20q?-qter & gain & $>30$ & yes & $2(66 \%)$ \\
\hline
\end{tabular}

Specimens were from [12] and the Progenetix data base, with an incidence of at least $20 \%$. These aberrations were also seen in the cell lines of our study but with a higher percentage of affected samples. 


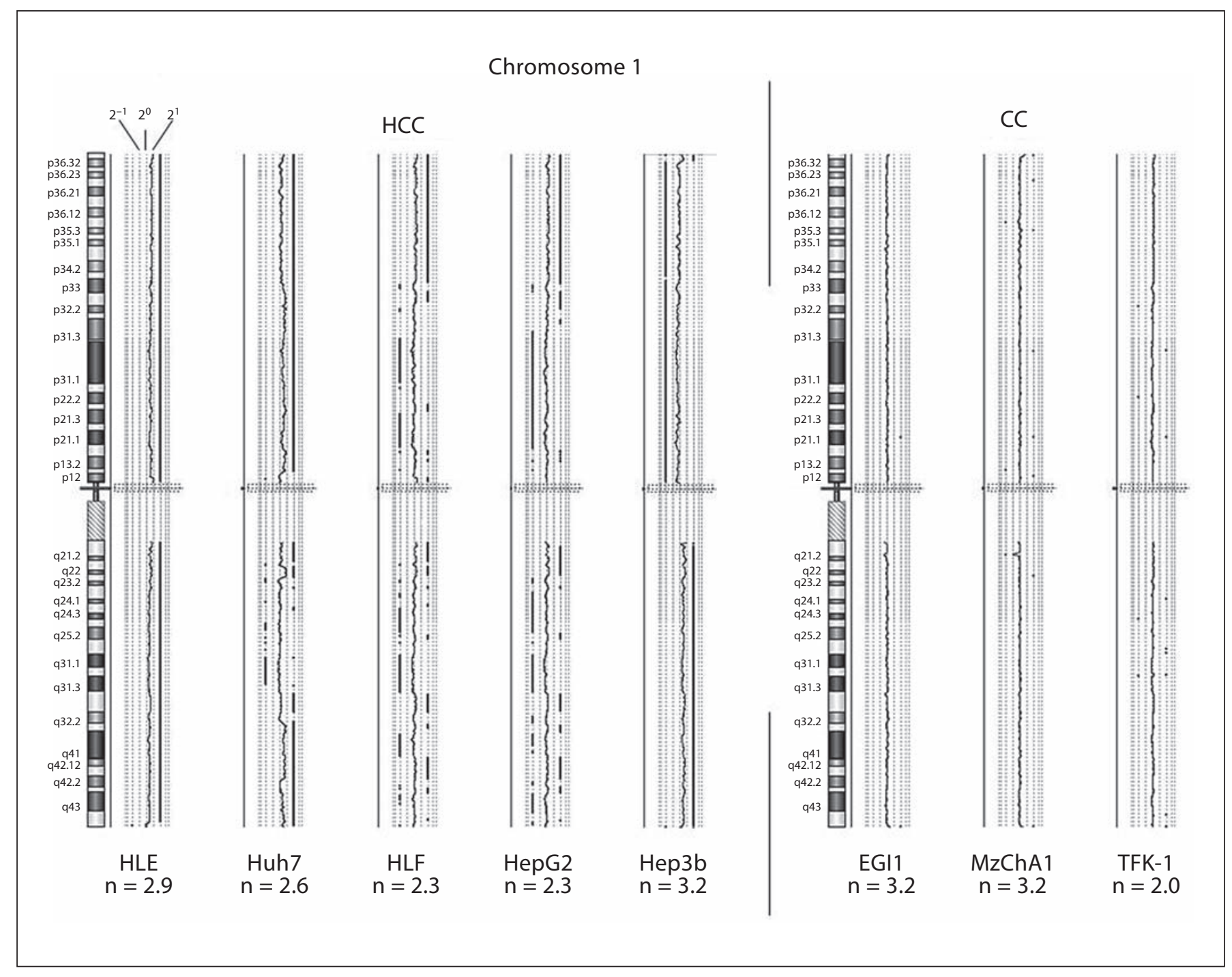

Fig. 1. Findings of aCGH for chromosome 1 . A very specific finding was that easily detectable gains of parts of $1 \mathrm{q}$ are seen in all HCC cell lines. The mean number of chromosomes in a nucleus (listed in table 2) is given below the name of the cell lines. There was no correlation of this mean number and the type of cell line (HCC vs. $\mathrm{CC}$ ) or any of the structural aberrations found by aCGH.

histological differentiation of CC cell lines Mz-ChA-1 and TFK-1. Cell line Mz-Cha-1 revealed a moderate-tolow differentiation and TFK-1 a low differentiation in the histological examination (fig. 5).

\section{Group $1 b$}

Chromosomal imbalances seen only in CC cell lines but in none of the HCC cell lines were not detectable. However, for chromosome 8, a combination of imbalances occurred in CC cell lines only. There was a gain of $8 \mathrm{q}$ spanning 8q13-qter for all 3 samples (fig. 2). This gain was accompanied by a loss of the remaining chromosome, i.e. $8 p$ in $2 \mathrm{CC}$ cell lines. The difference in the signal ratio of the loss of $8 p$ and the gain of $8 \mathrm{q}$ was at least 0.5 , indicating a relative gain of $8 \mathrm{q}$ of at least 1 additional copy. For cell line TFK-1, a loss of $8 \mathrm{p}$ was not indicated by a deviation of the signal ratio line and FISH results did not reveal aberrant counts for this region; however, signal ratios for $8 \mathrm{p}$ and $8 \mathrm{q}$ differed from values described for the other 2 cell lines.

HCC cell lines also demonstrated aberrations of chromosome 8. Four of the HCC cell lines revealed a 


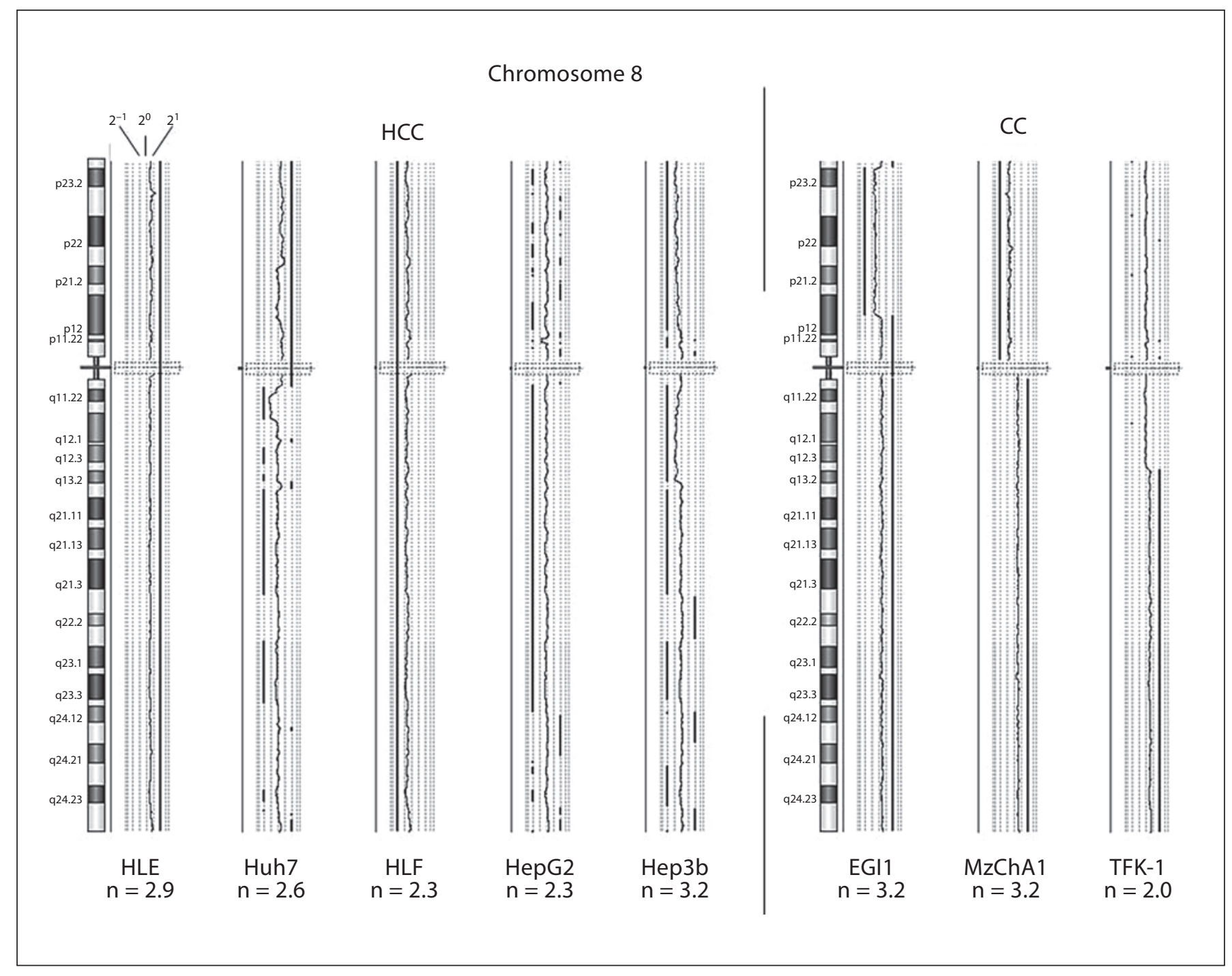

Fig. 2. aCGH for chromosome 8 revealed imbalances of chromosome arms $8 \mathrm{p}$ and $8 \mathrm{q}$, giving a clue for $\mathrm{i}(8 \mathrm{q})$. In contrast, aberrations of chromosome 8 in HCC cell lines were more variable.

nearly complete loss or gain of the chromosome. In cell line Hep3b, a loss of major parts of the chromosomes was seen, interrupted by some areas of gain in the long arm. There was, however, no consistent loss of $8 \mathrm{p}$ in comparison to $8 \mathrm{q}$.

\section{Group 1c}

The only chromosomal aberration found in both kinds of cell lines and in all samples was $17 q+$ spanning bands q22-qter (fig. 4). In HCC cell lines, as seen for larger parts of $17 \mathrm{p}$, the more proximal chromosomal bands up to $\mathrm{q} 12$ were also gained. However, gain of $17 p$ was not complete, but interrupted for regions p11 and p13-qter in 4 samples. In contrast, in CC, a loss of $17 \mathrm{p}$ was seen in 2 samples (EZI1, MzCha-1). For TFK-1, a loss of 17p was not found (confirmed by FISH); however, there was also an imbalance in the sense of a relative loss of $17 p$ in comparison to $17 q$.

\section{Group 2}

Within this group we collected chromosomal imbalances that were seen in all HCC or CC cell lines, but reported in less than $5 \%$ of surgical tumor specimens in the 


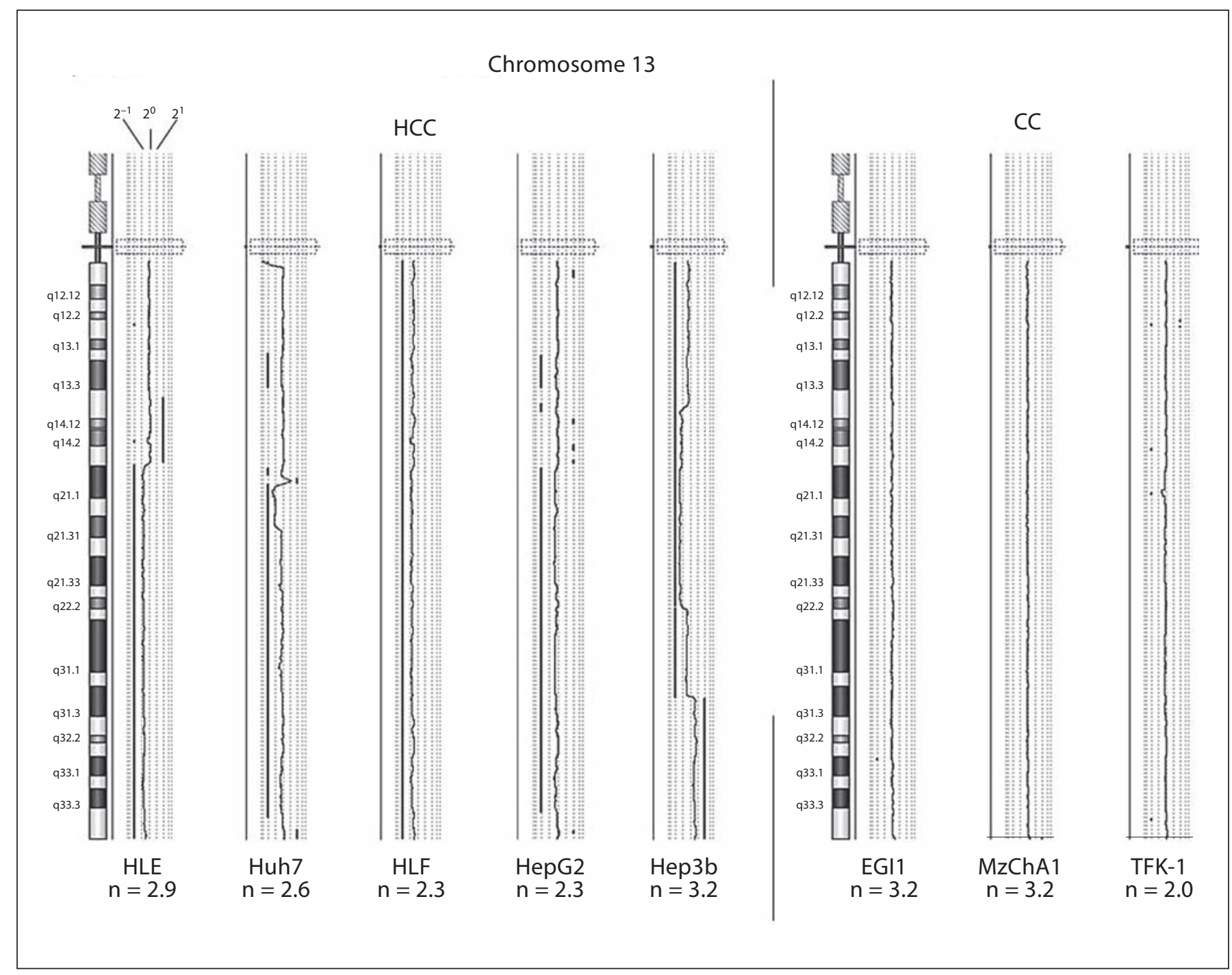

Fig. 3. Chromosomal imbalances of chromosome 13 focused on 13q. aCGH detected a region spanning from q14.12 to q31.3. This aberration was not seen in CC cell lines. However, histological examination of in vivo grown tumor cells of 2 of the CC cell lines showed a moderate differentiation of the carcinoma, as depicted in figure 5 .

literature. By this criterion, partial or complete gains of $11 p, 12 p, 14 q, 16 p, 16 q, 21 q$ and $22 q$ were included in this group.

\section{Discussion}

Cell lines are an important system for evaluating pharmacological and toxicological effects in humans [13]. They often also reveal the basic mechanisms of tumor growth and development and are a frequently used source for research purposes [14]. Moreover, they represent a pure population of tumor cells without an admixture of inflammatory cells or fibroblasts, for example, typically seen as a desmoplastic reaction in solid tumors. This decreases the threshold for the detection of tumor-specific terations such as genomic imbalances; however, cell lines of solid tumors are difficult to establish. This observation is still poorly understood and it is questionable whether there is a bias for successfully maintaining such cells in vitro. We therefore looked for chromosomal imbalances that part HCC cells from CC cells and/or for aberrations 


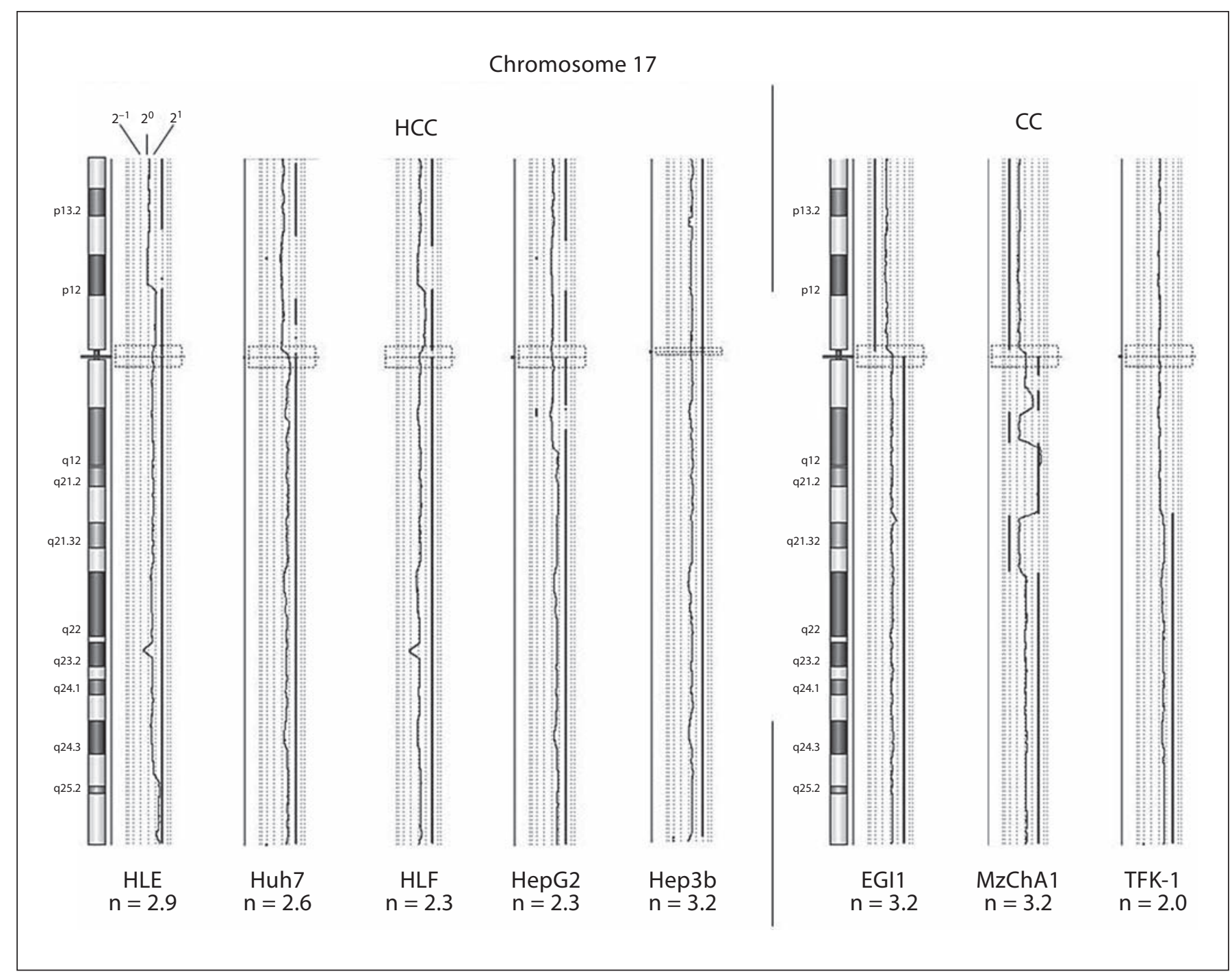

Fig. 4. Chromosome 17 was the only chromosome aberrant in all cell lines. In particular, the long arm of this chromosome was always affected. However, as seen for chromosome 8 , the pattern of aberrations varied. Nevertheless, gain of chromosomal material distal to q21.32 was detected in all samples.

probably needed for the successful in vitro culture of tumor cells.

Chromosomal imbalances parting HCC cell lines from CC cell lines were taken together in group 1. Here, we found gains of $1 \mathrm{q}$ at first. This was expected since these aberrations are reported most frequently in surgical tumor specimens with $57 \%$ of cases affected by gains of 1q21-2 as shown in a meta-analysis of 785 samples using conventional CGH analysis [12], and in $90 \%$ of samples using aCGH [15]. Similar reports have been made for the regions more distal on $1 \mathrm{q}$ including $\mathrm{q} 23$, q32 and $\mathrm{q} 42$, re- spectively. We therefore assume these aberrations to be a basic event in carcinogenesis in surgical tumor samples as well as in cell lines of hepatocellular origin.

A further aberration seen in all HCC cell lines but in none of the CC cell lines was the loss of 13q14-q31.1. Losses of $13 \mathrm{q}$ have been reported in $27 \%$ of surgical specimens of HCC as a sign of dedifferentiation [12]. The loss is also seen in the context of increasing chromosomal instability $[16,17]$. Deletion of $13 q$ has been reported in other solid tumors, but with a frequency of less than $5 \%$ [18]. A recent study reported a loss of 13q occuring in CC 

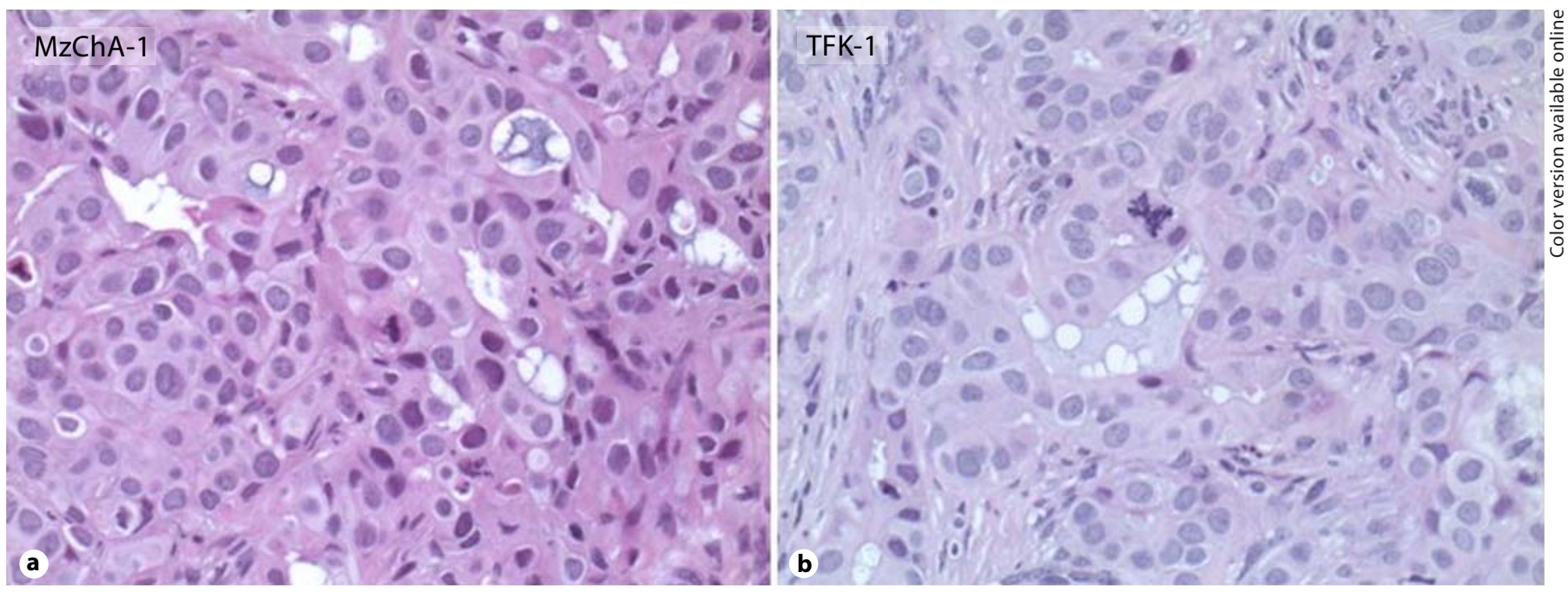

Fig. 5. Tumor specimens of cell lines MzChA-1 and TFK-1 grown in nude mice (kindly provided by N. Malek). For both cell lines, no loss of $13 \mathrm{q}$ was found and in both tumor samples a moderate (but not low) differentiation was seen.

[19]; however, conventional CGH was used with a much lower resolution of approximately $1 \mathrm{MB}$. Moreover, the authors did not include which part of the chromosome arms were affected but only listed aberrations as a loss or gain of complete arms, which is not precise. As 13q deletion is reported as a sign of dedifferentiation, we wondered whether the CC cell lines not bearing this aberration were of low differentiation or not. We therefore conducted a histological examination, by placing tumor cells into a mouse model. This was done successfully for 2 cell lines. Both of them revealed a moderate differentiation after in vivo growth. We therefore assume that where there is not a loss of 13q, this is in the context of a preserved capability of tumor cells to differentiate, rather than it being a characteristic of cholangiolar differentiation.

Imbalances of chromosome 8 were also helpful in differentiating HCC cell lines from CC cell lines. A gain of 8q13-qter occurred in all CC cell lines. In HCC cell lines, a part of 8q was gained in 3 of 5 cell lines only. Interestingly in CC cell lines, the gain of $8 \mathrm{q}$ was accompanied by a loss of at least one copy of $8 p$ in relation to $8 \mathrm{q}$. This could be discussed as an isochromosome $8 \mathrm{q}[\mathrm{i}(8 \mathrm{q})]$. This kind of aberration is the second most common isochromosome in human neoplasia and is frequently found in solid tumors such as adenocarcinoma (of the lung $22 \%$, colon $15 \%$, stomach $12 \%$ ) and malignant melanoma (17\%) [20]. It is frequently seen in acute myeloid leukemia and myelodysplastic syndrome and data on malignant melanoma also suggest it is a secondary rather than a primary aberration [20]. No data are available to suggest which of the aberrations, gain of $8 \mathrm{q}$ or loss of $8 \mathrm{p}$ has the greater effect on tumor progression. To date, gain of $8 \mathrm{q}$ seems to be the more important abnormality. This is not in full accordance with earlier reports demonstrating $i(8 q)$ in a large number of HCC cell lines and in correlation with a dedifferentiation and chromosomal instability [11].

Loss of the short and gain of the long arm of a chromosome were also seen for chromosome 17. Indeed, this chromosome was the only one revealing the same aberration in all HCC and CC samples, i.e. gain of q21-qter. However, the regions spanned by this aberration were different, with HCC cell lines having a gain of 17q including the centromeric region and for some cases also parts of $17 p$. In CC cell lines, $17 q+$ was seen in varying extents with a common gained region starting at q21. Interestingly, in all CC cell lines, the gain of 17q was accompanied by a relative loss of $17 \mathrm{p}$. We do not assume this finding to be an isochromosome $\mathrm{i}(17 \mathrm{q})$, since the typical breaking region of $\mathrm{i}(17 \mathrm{q})$ spans an interval of approximately $240 \mathrm{kB}$ in the Smith-Magenis syndrome common deletion region in 17p11.2 [21]. Losses of $17 \mathrm{p}$ were not seen in HCC cell lines. Indeed, 4 of 5 cell lines revealed a gain of $17 p$ interrupted by a not-gained region spanning from $17 \mathrm{p} 12$ to 13.2 . 
Besides these aberrations occurring frequently in our cell lines and in surgical specimens, we found HCC cellline imbalances to be reported only rarely in the latter. These included gains of 11p, 12,14q, 16p, 16q, 21q and 22q. Imbalances of these chromosomes are also rarely $(<10 \%)$ found to occur in other solid tumors with the exception of chromosomes 12 and 16; 12p is gained in tumors of the female and male genital tract [22] and $16 \mathrm{q}$ is altered by losses and not gains in lobular carcinoma and lobular carcinoma in situ [23, 24]. It is assumed that ECadherin is lost as a consequence of this aberration leading to the development of the lobular phenotype. Loss of $16 \mathrm{q}$ in such cases is frequently accompanied by a gain of $16 \mathrm{p}$.

Taking these findings together, there are chromosomal imbalances found in surgical specimens of $\mathrm{HCC} / \mathrm{CC}$ as well as in the cell lines. In part, these aberrations are typical for hepatic and/or cholangiolar differentiation. There are also imbalances detectable in cell lines prob- ably necessary for ongoing tumor cell growth in vitro. These aberrations are found rarely in the surgical tumor specimens. However, it is not clear why they occur. It may be speculated that the imbalances could already be in the tumor cells from which the cell lines are derived, in which case it would have to be assumed that these aberrations are helpful for the tumor cells to maintain in vitro. On the other hand, these aberrations could occur as secondary events, giving a growth advantage for the tumor cells in vitro. The question which of these alternatives applies could only be answered by the culture of cloned cells obtained directly from surgical tumor specimens.

In conclusion, carcinoma cell lines of hepatic and cholangiolar origin can be separated by aberrations of chromosomes such as 1, 8 and 13. There are, nevertheless, aberrations shared by all cell lines such as $17 \mathrm{q}+$. It will be of interest to investigate the implications of these aberrations in further detail.

\section{References}

1 Schirmacher P, Dienes HP: Hepatocellular carcinoma; in Kurzrock R, Talpaz M, (eds): Molecular Biology in Cancer Medicine. London, Dunitz, 1999, pp 355-366.

2 El-Serag HB: Hepatocellular carcinoma: an epidemiologic view. J Clin Gastroenterol 2002;35:72-78.

3 Wu CG, Salvay DM, Forgues M, Valerie K, Farnsworth J, Markin RS, Wang XW: Distinctive gene expression profiles associated with hepatitis $\mathrm{B}$ virus $\mathrm{x}$ protein. Oncogene 2001;20:3674-3682.

-4 Smith MW, Yue ZN, Geiss GK, Sadovnikova NY, Carter VS, Boix L, Lazaro CA, Rosenberg GB, Bumgarner RE, Fausto N, Bruix J, Katze MG: Identification of novel tumor markers in hepatitis $C$ virus-associated hepatocellular carcinoma. Cancer Res 2003;63: 859-864.

5 Okabe H, Satoh S, Kato T, Kitahara O, Yanagawa R, Yamaoka Y, Tsunoda T, Furukawa Y, Nakamura Y: Genome-wide analysis of gene expression in human hepatocellular carcinomas using cDNA microarray: identification of genes involved in viral carcinogenesis and tumor progression. Cancer Res 2001;61: 2129-2137.

-6 Iizuka N, Oka M, Yamada-Okabe H, Hamada K, Nakayama H, Mori N, Tamesa T, Okada T, Takemoto N, Matoba K, Takashima M, Sakamoto K, Tangoku A, Miyamoto T, Uchimura S, Hamamoto Y: Molecular signature in three types of hepatocellular carcinoma with different viral origin by oligonucleotide microarray. Int J Oncol 2004;24:565-574.
7 Neo SY, Leow CK, Vega VB, Long PM, Islam AF, Lai PB, Liu ET, Ren EC: Identification of discriminators of hepatoma by gene expression profiling using a minimal dataset approach. Hepatology 2004;39:944953.

8 Miller G, Socci ND, Dhall D, D'Angelica M, DeMatteo RP, Allen PJ, Singh B, Fong Y, Blumgart LH, Klimstra DS, Jarnagin WR: Genome wide analysis and clinical correlation of chromosomal and transcriptional mutations in cancers of the biliary tract. J Exp Clin Cancer Res 2009;28:62.

$\checkmark 9$ Randi G, Franceschi S, La Vecchia C: Gallbladder cancer worldwide: geographical distribution and risk factors. Int J Cancer 2006; 118:1591-1602.

10 Valle J, Wasan H, Palmer DH, Cunningham D, Anthoney A, Maraveyas A, Madhusudan S, Iveson T, Hughes S, Pereira SP, Roughton $\mathrm{M}$, Bridgewater J: Cisplatin plus gemcitabine versus gemcitabine for biliary tract cancer. $\mathrm{N}$ Engl J Med 2010;362:1273-1281.

11 Hertz S, Rothamel T, Giere C, Skawran B, Steinemann D, Flemming A, Becker T, Flik J, Wiese B, Kreipe H, Schlegelberger B, Wilkens $\mathrm{L}$ : Losses of chromosome arms $4 \mathrm{q}$ and $13 \mathrm{q}$ are correlated with increasing chromosomal instability and gains of 8q with increasing polyploidy in hepatocellular carcinoma. Pathobiology 2008;75:312-322.
12 Moinzadeh P, Breuhahn K, Stutzer H, Schirmacher P: Chromosome alterations in human hepatocellular carcinomas correlate with aetiology and histological grade - results of an explorative CGH meta-analysis. Br J Cancer 2005;92:935-941.

13 Liguori MJ, Anderson MG, Bukofzer S, McKim J, Pregenzer JF, Retief J, Spear BB, Waring JF: Microarray analysis in human hepatocytes suggests a mechanism for hepatotoxicity induced by trovafloxacin. Hepatology 2005;41:177-186.

14 Yang W, Yan HX, Chen L, Liu Q, He YQ, Yu LX, Zhang SH, Huang DD, Tang L, Kong XN, Chen C, Liu SQ, Wu MC, Wang HY: Wnt/ beta-catenin signaling contributes to activation of normal and tumorigenic liver progenitor cells. Cancer Res 2008;68:42874295

15 Steinemann D, Skawran B, Becker T, Tauscher M, Weigmann A, Wingen L, Tauscher S, Hinrichsen T, Hertz S, Flemming P, Flik J, Wiese B, Kreipe H, Lichter P, Schlegelberger B, Wilkens L: Assessment of differentiation and progression of hepatic tumors using array-based comparative genomic hybridization. Clin Gastro Hepatol 2006;4:1283-1291.

16 Skawran B, Steinemann D, Becker T, Buurman R, Flik J, Wiese B, Flemming P, Kreipe $\mathrm{H}$, Schlegelberger B, Wilkens L: Loss of $13 \mathrm{q}$ is associated with genes involved in cell cycle and proliferation in dedifferentiated hepatocellular carcinoma. Mod Pathol 2008;21: 1479-1489. 
- 17 Hertz S, Rothamel T, Giere C, Skawran B, Steinemann D, Flemming A, Becker T, Flik J, Wiese B, Kreipe H, Schlegelberger B, Wilkens L: Losses of chromosome arms $4 \mathrm{q}$ and $13 \mathrm{q}$ and gain of $8 \mathrm{q}$ are correlated with increasing chromosomal instability in hepatocellular carcinoma. Pathobiology 2008;75: 312-322.

18 Dessen P, Knuutila S, Huret JL: Chromosome 13. Atlas of Genetics and Cytogenetics in Oncology and Haematology. 2004. http:// AtlasGeneticsOncology.org/Indexbychrom/ idxa_13.
9 Homayounfar K, Gunawan B, Cameron S, Haller F, Baumhoer D, Uecker S, Sander B, Ramadori G, Lorf T, Fuzesi L: Pattern of chromosomal aberrations in primary liver cancers identified by comparative genomic hybridization. Hum Pathol 2009;40:834842 .

20 Mertens F, Johansson B, Mitelman F: Isochromosomes in neoplasia. Genes Chromosomes Cancer 1994;10:221-230.

21 Carvalho CM, Lupski JR: Copy number variation at the breakpoint region of isochromosome 17q. Genome Res 2008;18: 1724-1732.

22 Dessen P, Knuutila S, Huret JL: Atlas of Genetics and Cytogenetics in Oncology and Haematology, Chromosome 12. Atlas of Genetics and Cytogenetics in Oncology and Haematology. 2004. http:// AtlasGeneticsOncology.org/Indexbychrom/ idxa_12.
3 Hwang ES, Nyante SJ, Yi CY, Moore D, DeVries S, Korkola JE, Esserman LJ, Waldman FM: Clonality of lobular carcinoma in situ and synchronous invasive lobular carcinoma. Cancer 2004; 100:2562-2572.

24 Chen YY, Hwang ES, Roy R, DeVries S, Anderson J, Wa C, Fitzgibbons PL, Jacobs TW, MacGrogan G, Peterse H, Vincent-Salomon A, Tokuyasu T, Schnitt SJ, Waldman FM: Genetic and phenotypic characteristics of pleomorphic lobular carcinoma in situ of the breast. Am J Surg Pathol 2009;33:16831694. 